\title{
Investigating the effect of Crataegus pinnatifida, a functional food, on cognition and memory deficit
}

\author{
Jihye Lee ${ }^{1}$, Sang Hyeok Park ${ }^{1}$, Chanhee Lee ${ }^{1}$, Hye-Jeong Kim ${ }^{1}$, Chul Jong Jung ${ }^{2}$, \\ Gyung Yun Beik ${ }^{2}$, Jin Gi Shin ${ }^{2}$, Ji Wook Jung ${ }^{1 *}$ \\ ${ }^{1}$ Department of Pharmacology, Daegu Haany University, Gyeongsan 38578, Korea \\ ${ }^{2}$ Okchundang Corporation, Daegu 41059, Korea
}

\section{인지 및 기억 개선 기능성 식품으로서 산사의 효과}

\author{
이지혜 ${ }^{1} \cdot$ 박상혁 $^{1} \cdot$ 이찬희 ${ }^{1} \cdot$ 김혜정 ${ }^{1} \cdot$ 정철종 ${ }^{2} \cdot$ 백경연 $^{2} \cdot$ 신진기 $^{2} \cdot$ 정지욱 ${ }^{1 *}$ \\ ${ }^{1}$ 대구한의대학교 약리학연구실, ${ }^{2}$ (주)옥천당
}

\begin{abstract}
Crataegus pinnatifida (hawthorn) is highly popular as a pleasant-tasting functional food and herb that can also be used for treating cardiovascular diseases. The improvements in learning and memory brought about by $C$. pinnatifida have been investigated, and the mechanism of action in scopolamine-induced amnesia model in mice was elucidated. C. pinnatifida extract was orally administered to the mice, and scopolamine, a muscarinic acetylcholine receptor antagonist, was injected 30 min before the Y-maze, passive avoidance, and Monis water maze test. It was observed that $C$. pinnatifida extract improved the percentage of spontaneous alternation, increased the step-through latency, and shortened the escape latency, respectively. $C$. pinnatifida extract contained $380.70 \mathrm{kcal}$ energy, which had contributions from carbohydrate $(92.5 \%)$, sugars $(92.4 \%)$, crude protein $(1.1 \%)$ and crude fat $(0.7 \%)$. Polyphenol and flavonoid contents assessed using Folin-Denis' reagent and aluminium nitrate revealed $9.8 \pm 0.3 \mathrm{mg}$ tannic acid equivalent/g of polyphenol and $18.9 \pm 0.4 \mathrm{mg}$ quercetin equivalent/g of flavonoid, respectively. Furthermore, $C$. pinnatifida extract inhibited acetylcholinesterase in the whole brain. Taken together, this study demonstrated that C. pinnatifida ameliorated memory and cognitive function, indicating that it might be useful as a functional food and could also be an efficient candidate as an anti-amnesia agents.
\end{abstract}

Key words : Crataegus pinnatifida, scopolamine, amnesia, memory

\section{서 론}

퇴행성 질환인 치매는 현대사회가 빠르게 고령화 되어 감에 따라 계속해서 증가하고 있는 질환으로 2015년 World Health Organization(WHO)는 전세계의 4,800만 명의 사람 들이 치매를 겪고 있다고 보고하였다(1). 치매의 가장 큰 증상은 인지 및 기억력 손상인데 이로 인하여 대인관계가

*Corresponding author. E-mail : jwjung@dhu.ac.kr

Phone : 82-53-819-1337, Fax : 82-53-819-1339

Received 7 December 2018; Revised 3 January 2019; Accepted 7 January 2019.

Copyright (c) The Korean Society of Food Preservation. All rights reserved.
어려워지고 사회 생활이 힘들어져 경제적인 어려움을 겪게 되는 등 사회적, 경제적 문제로 대두되고 있다. 치매 중 대표적인 alzheimer's disease(AD)의 병인은 정확하지는 않 지만 베타 아밀로이드의 응집(2), 타우 단백질의 과인산화 (3), 콜린성 신경계의 저하(4), 신경 세포의 사멸(5) 등 다양 하게 병리 생리학적으로 이야기하고 있다. 현재 $\mathrm{AD}$ 치료제 로 사용되는 약물은 대부분이 acetylcholinesterase(AChE) 억제제로 tacrine, rivastigmine, galatamine, donepezil과 N-methyl-D-aspartate(NMDA) 수용체 효현제인 memantine 이 있는데(6) 메스꺼움, 구토, 변비, 설사와 같은 소화기계 이상, 간독성, 근육피로, 두통, 수면장애 등 다양한 부작용 $(7,8)$ 으로 인하여 보완하거나 대체할 부작용이 없는 약물에 대한 연구가 진행되고 있다. 
산사는 장미과(Rosaceae)에 속한 낙엽 소교목인 산사나 무(Crataegus pinnatifida Bunge) 및 동속 근연식물의 잘 익 은 열매로 우리나라를 비롯한 중국, 일본 전역에 자생하고 특유의 향과 달고 신맛이 난다. 예로부터 한방에서 건위제, 소화제, 정장제로 사용되어왔고 유럽에서는 hawthorn berry 라고 하여 심장 질환(9), 고혈압, 동맥경화 등에 사용되어 왔다. 산사에는 hyperoside, chlorogenic acid, vitexin, epicatechin, isoquercitrin 등과 같은 활성 성분을 지니고 있 는데 $(10,11)$ 그 중 대표적인 성분인 hyperoside는 만성적인 mild stress에 의한 학습 및 기억 개선 손상을 brain-derived neurotrophic factor(BDNF) signaling 증가를 통한 개선(12), 베타 아밀로이드에 의한 신경손상 보호(13) 및 항우울 효과 (14)에 대해 보고 되었고, chlorogenic acid는 스트레스 호르 몬으로 유발된 monoamine oxidase $\mathrm{B}(\mathrm{MAOB})$ 의 활성과 reactive oxygen species(ROS)의 생성을 막고 항우울 효과 (15), 인지 및 신경 보호 효과(16)를 나타내었다. Vitexin은 $\mathrm{PI} 3 \mathrm{~K} / \mathrm{Akt}$ 경로를 활성화하여 methyl-4-phenylpyridine(MPP+) /1-methyl-4-phenyl-1,2,3,6-tetrahydropyridine(MPTP) 유도 한 신경 손상에 대한 dopaminergic 신경 보호(17), mitogenactivated protein kinase(MAPK)와 세포 자멸사를 조절하여 허혈성 뇌 손상을 보호(18)하는 것이 보고되었다. 최근 씨에 서 발견된 새로운 sesquineolignan인 hawthornsesquinins $\mathrm{K}$ 와 $\mathrm{L}$ 이 베타 아밀로이드 응집을 억제하고 $\mathrm{H}_{2} \mathrm{O}_{2}$ 유도된 손상 된 세포에서 신경 보호 효과(19)가 보고되었을 뿐만 아니라 산사의 다양한 성분들의 항산화 효과(20), 항염증 효과(21), 항균효과(22) 등이 보고되었다. 이러한 성분을 포함한 산사 의 추출물 역시 제 2 형 당뇨병에서 저혈당 효과(23), 죽상동 맥경화 감소 효과(9), 갱년기 보호 효과(24), 항산화 효과 (25), 지질 개선 효과(26) 등에 대해 보고되었고 요즘에는 차, 음료, 젤리, 과자 등 다양한 형태의 식품으로 시판되고 있다. 산사나무의 열매 뿐만 아니라 잎, 뿌리, 씨에는 영양 성분도 풍부한데 glutamic acid와 asparagine과 같은 아미노 산, 칼슘, 인, 마그네슘 등 무기질과 비타민, 지방, 단백질 등이 포함 $(27,28)$ 되어 있어 medicinal food, functional food 로 활용 가치가 높다.

따라서 본 연구에서는 국산 산사가 기능성 식품으로서 인지 및 기억력 개선에 도움을 줄 가능성이 있는지를 알아 보고자 scopolamine으로 유도한 기억 손상 마우스에 프레타 놀(prethanol)을 이용한 산사 추출물을 경구 투여하여 행동 실험인 $\mathrm{Y}$ 미로 시험, 수동 회피 시험, 모리스 수중 미로 시험을 수행하였고 그 기전을 알아보기 위하여 acetylcholinesterase(AChE)의 활성을 측정하였다. 또한 산 사의 영양성분 및 항산화능을 측정하여 안전성을 확보하고 이 결과를 기반으로 인지 및 기억력 손상을 예방, 관리 및 개선을 위한 산사의 우수성을 알리기 위한 기반자료로 활용 하고자 한다.

\section{재료 및 방법}

\section{실험재료}

본 실험에 사용된 국산 산사는 (주옥천당(Daegu, Korea)에 서 구입하여 사용하였다. 국산 산사는 에탄올의 함량, 온도, 시간이 길어질수록 높은 수득율을 나타내었으나 본 연구에 서는 대량 생산시 안전성을 위하여 $60 \%$ 프레타놀을 이용하 여 $60^{\circ} \mathrm{C}$ 에서 5 시간 추출 후 감압 여과하고, rotatory vacuum evaporator(Eyela, Tokyo, Japan)으로 감압 농축하여 농축물 의 고형분 함량을 측정한 뒤 덱스트린과 $1: 1$ 비율로 분무 건조하여 가루 형태로 만들어 $-20^{\circ} \mathrm{C}$ 에 보관하며 실험에 사 용하였다(Yield: $10.2 \%$ ).

Scopolamine과 donepezil는 Sigma-Aldrich(St. Louis, MO, USA)의 제품을 사용하였고 나머지 시약은 시중에서 구입 할 수 있는 최상급을 사용하였다.

\section{실험동물}

4주령 수컷 ICR mouse를 대한바이오링크(Eumseong, Korea)로부터 공급받아 1 주일 동안 순화 후 실험에 사용하 였다. 사육기간 중 식이와 물은 자유 섭취시켰으며 사육실 온도는 $23 \pm 1^{\circ} \mathrm{C}$, 습도 $50 \pm 5 \%$, 조명시간 07:00-19:00(12시간 주기)로 환경을 유지하였다. 순환 기간을 거친 실험 동물에 게 행동 실험 1 시간 전 산사 분무 건조물(spray-dried Crataegus pinnatifida extract, SCP) $6.25-50 \mathrm{mg} / \mathrm{kg}$ 를 단회 경구 투여하고 30 분 뒤 scopolamine $1 \mathrm{mg} / \mathrm{kg}$ 을 복강 투여하 여 기억 손상을 유발하였다. 본 연구에서 진행된 동물실험 절차는 대구한의대학교 동물실험윤리위원회의 사전심의 와 윤리 규정을 준수하여 수행하였다(승인번호: DHU2017087).

\section{총 폴리페놀 정량}

총 폴리페놀 함량은 Folin과 Denis(29)법에 따라 시료 $0.1 \mathrm{~mL}$ 과 증류수 $0.9 \mathrm{~mL}$ 을 혼합액에 $50 \%$ Folin-Ciocalteu's phenol reagent $0.1 \mathrm{~mL}$ 을 첨가하여 3분간 반응 시킨 후 $10 \%$ $\mathrm{Na}_{2} \mathrm{NO}_{3}$ 용액 $0.2 \mathrm{~mL}$ 과 증류수 $0.7 \mathrm{~mL}$ 을 가하여 상온에서 1시간 반응 후 $725 \mathrm{~nm}$ 에서 흡광도(Sunrise, Tecan, Männedorf, Switzerland)를 측정하였다. 표준물질로써 tannic acid(Sigma-Aldrich)를 사용하여 검량선을 작성한 다 음 정량하여 계산하였다.

\section{총 플라보노이드 정량}

총 플라보노이드 함량은 Moreno 등(30)의 방법에 따라 시료 $0.5 \mathrm{~mL}$ 에 $10 \%$ aluminum nitrate $0.1 \mathrm{~mL}, 1 \mathrm{M}$ potassium acetate $0.1 \mathrm{~mL}$ 및 $80 \%$ ethanol $4.3 \mathrm{~mL}$ 을 가하여 상온에서 40 분간 반응 후 $415 \mathrm{~nm}$ 에서 흡광도(Sunrise, Tecan)를 측정 하였다. 표준물질로써 quercetin(Sigma-Aldrich)을 사용하 여 검량선을 작성한 다음 정량하여 계산하였다. 


\section{Y-미로 시험}

단기 기억력을 측정하는 실험으로 순차적으로 행동하는 능력을 평가하기 위한 방법으로 Y-maze test 실시하였다 (31). 측정 장비는 세 개의 가지로 구성되어 있으며 각 가지 의 길이는 $42 \mathrm{~cm}$, 넓이는 $3 \mathrm{~cm}$, 높이는 $12 \mathrm{~cm}$ 이고 세 가지가 접히는 각도는 $120^{\circ}$ 이다. 이 장치는 검정색의 polyvinyl plastic으로 구성되어 있고, 세 개의 가지를 각각 $\mathrm{A}, \mathrm{B}, \mathrm{C}$ 로 정한 뒤에 실험을 진행하였다. 실험동물을 넣고 8 분 동안 각 가지에 실험동물의 꼬리까지 가지에 들어갈 때의 횟수 와, 각 가지에 차례로 들어간 경우를 헤아려 1점(실제변경, actual alternation)씩 부여하였다. 변경 행동력(alternation behavior)은 세 가지 모두에 겹치지 않게 들어가는 것으로 정의되며, 다음의 수학식에 의해 자발적 변경 행동력 (spontaneous alteration)을 계산하였다.

Spontaneous alteration $(\%)=\frac{\text { actual alternation }}{\text { maximum alternation }} \times 100$

최고변경: 총 입장횟수-2

\section{수동 회피 시험}

해마의 조건화된 기억과 변연계와 관련 있는 기억에 관 한 영향 및 working memory ability를 평가하기 위해 회피학 습상자(Jeung Do Bio \& Plant Co., Ltd., Seoul, Korea)를 이용하여 실험을 하였다(32). 수동회피 상자는 어두운 방과 밝은 방으로 나누어져 있으며, 밝은 방에 실험동물을 넣으 면 어두운 방으로 넘어가는데 그 순간 5 초간 $0.5 \mathrm{~mA}$ 의 전기충격을 가한다. 전기충격을 가한 다음 날 실험동물을 밝은 방에 다시 넣었을 때 어두운 방에서의 전기충격을 기억하여 밝은 방에 머무르게 되는데, 이때 체류하는 시간 (step-through latency)을 측정하여 기억력을 평가하였다.

\section{모리스 수중 미로 시험}

해마 의존적 공간학습 및 장기 기억력 개선에 대한 실험 으로(33) 원형으로 된 지름 $90 \mathrm{~cm}$, 높이 $45 \mathrm{~cm}$ 의 수조의 사분면 한 구역에 지름 $9 \mathrm{~cm}$, 높이 $25 \mathrm{~cm}$ 의 도피대를 설치하 고 $20 \pm 2^{\circ} \mathrm{C}$ 깨끗한 물을 도피대 보다 $1 \mathrm{~cm}$ 정도 위로 채운 뒤 실험 동물이 도피대를 찾아가는데 걸리는 시간을 측정하 였다. 원형 수조에서 4 개의 표지판을 설치하여 4 분면으로 나누어 입수하는 위치를 다르게 하여 하루 4번씩 반복하여 60 초간 진행하였으며 실험 동물이 60 초 안에 도피대를 찾 으면 실험을 완료하였고 찾지 못한 경우 손으로 위치를 안내해주어 10초간 머무르게 하였다. 실험 마지막 날 도피 대를 제거하고 학습능력을 측정하기 위해 60 초간 도피대가 있었던 구역에 머무르는 시간을 측정하였고 모든 실험은 Ethovision program(Noldus, Netherlands)을 이용하여 기록 및 측정하였다.

\section{아세틸콜린에스테라아제 활성 시험}

$\mathrm{AChE}$ 활성 억제능은 Ellman 등 (34)의 방법인 acetylthiocholine iodide(ASCh, Sigma-Aldrich)를 기질로 사 용한 비색분석법으로 실험하였다. 실험에 사용하지 않은 실험 동물을 경추 탈골 후 전체 뇌를 적출하여 차가운 sodium phosphate buffer(100 mM, pH 8.0)를 이용하여 균질 화하고, $12,500 \mathrm{rpm}, 20$ 분간 원심분리 후 얻은 상층액으로 $\mathrm{AChE}$ 활성을 측정하는 효소로 사용하였다. $\mathrm{SCP}$ 와 양성 대조군으로 사용한 donepezil(Sigma-Aldrich)을 단계별 희 석하여 사용하였다. Sodium phosphate buffer $134 \mu \mathrm{L}, 75$ $\mathrm{mM}$ ASCh $1 \mu \mathrm{L}, 10 \mathrm{mM}$ Ellman's 용액(5,5'-dithiobis2-nitrobenzoic acid) $5 \mu \mathrm{L}, \mathrm{SCP}$ 또는 donepezil을 $50 \mu \mathrm{L}$ 넣고 $25^{\circ} \mathrm{C}$ 에서 10 분간 반응 후 효소원 $10 \mu \mathrm{L}$ 를 넣고 $25^{\circ} \mathrm{C}$ 에서 5 분간 반응 후 $405 \mathrm{~nm}$ 에서 흡광도(Sunrise, Tecan)를 측정하 였다. 대조군으로는 효소를 첨가하지 않고 sodium phosphate buffer를 첨가한 반응액을 사용하였고, $\mathrm{ASCh}$ 를 첨가하지 않은 반응액으로 시료와 효소 활성용 시약간의 비특이적 반응이 일어나지 않았음을 확인하였다. 시료를 첨가하지 않은 반응액을 $\mathrm{AChE}$ 의 활성도를 $100 \%$ 로 하였을 때 각 시료를 첨가한 반응액의 $\mathrm{AChE}$ 활성 저해도를 그래프 로 나타내었다.

\section{통계 처리}

본 연구의 모든 실험 결과는 Prism 5(GraphPad Software, Inc., San Diego, CA, USA)를 사용하여 산출하였다. 그룹 간 유의성 검정은 일원배치분산분석(one-way analysis of variance)를 실시하고 Newman-Keuls test에 의해 유의수준 $\mathrm{p}<0.05$ 이상에서 사후검정을 실시하였다. 모든 결과는 mean \pm standard error of mean(SEM)으로 표시하였다.

\section{결과 및 고찰}

\section{영양성분}

식품공전에 따라 열량은 검체 $100 \mathrm{~g}$ 중의 조단백질, 조지 방 및 탄수화물 또는 당질의 함량에 단백질 4 , 지방 9 , 당질 4 의 계수를 곱하여 각각의 에너지를 칼로리 $(\mathrm{kcal})$ 단위로 산출하고 그 총계로 나타내고, 탄수화물은 시료 전체를 $100 \%$ 로 하여 에테르추출법으로 측정한 조지방, 세미마이 크로 킬달법으로 측정한 조단백질, 직접회화법으로 측정한 조회분, 상압가열건조법으로 측정한 수분을 제하여 나타내 었다. 산사 추출물의 영양성분은 Table 1 에 나타내었다. Park 등(27)의 연구와 유사하게 산사 $100 \mathrm{~g}$ 의 열량은 380.70 $\mathrm{kcal}$ 이고, 식물체의 구성성분인 탄수화물과 과실류에 따른 당의 비율이 높았다. 또한 검출되지 않은 콜레스테롤을 비 롯하여 지질 함량도 미비하여 건강 기능 식품으로 개발 가능할 것으로 판단된다. 
Table 1. Proximate compositions of the Crataegus pinnatifida

\begin{tabular}{|c|c|c|}
\hline \multicolumn{2}{|c|}{ Nutrients } & Contents \\
\hline \multicolumn{2}{|c|}{ Calories (kcal) } & 380.70 \\
\hline \multirow{4}{*}{ General nutrients (\%) } & Carbohydrate & 92.5 \\
\hline & Sugars & 92.4 \\
\hline & Crude protein & 1.1 \\
\hline & Crude fat & 0.7 \\
\hline \multicolumn{2}{|c|}{ Saturated fatty acid $(\mathrm{g} / 100 \mathrm{~g})$} & 0.5 \\
\hline \multicolumn{2}{|c|}{ Trans fat $(\mathrm{g} / 100 \mathrm{~g})$} & 0.00 \\
\hline \multicolumn{2}{|c|}{ Cholesterol (mg/100 g) } & Not detected \\
\hline \multicolumn{2}{|c|}{ Natrium (ng/100 g) } & 0.7 \\
\hline
\end{tabular}

\section{총 폴리페놀 함량}

페놀성 화합물은 방향성 화합물로 식물계에 널리 분포되 어 있는 2차 대사 산물로 고리구조상 hydroxyl기로부터 전 자를 공여하여 페놀 고리 구조 공명에 의해 구조적 안정화 가 되면서 항산화, 항염증, 항암 등 다양한 생리활성에 관여 하는 것으로 알려져 있다(35).

산사 추출물의 총 폴리페놀 함량을 정량한 결과를 Table 2 에 나타내었다. 산사 추출물의 총 폴리페놀 함량은 $9.8 \pm 0.3$

Table 2. Total phenolics and total flovonoids contents of Crataegus pinnatifida

\begin{tabular}{cc}
\hline $\begin{array}{c}\text { Total phenolics } \\
\left(\mathrm{mg} \mathrm{TAE}^{1)} / \mathrm{g}\right)\end{array}$ & $\begin{array}{c}\text { Total flavonoids } \\
\left(\mathrm{mg} \mathrm{QE}^{2} / \mathrm{g}\right)\end{array}$ \\
\hline $9.8 \pm 0.3^{3)}$ & $18.9 \pm 0.4$ \\
\hline
\end{tabular}

${ }^{1)}$ Tannic acid equivalent.

${ }^{2)}$ Quercetin equivalent.

${ }^{3)}$ Data are expressed as mean \pm SEM of triplicate determinations. $\mathrm{mg} \mathrm{TAE} / \mathrm{g}$ 으로 나타났다. Nam 등(36)이 에탄올 농도별 추 출 조건에서 $50 \%$ 에탄올 또는 $70 \%$ 에탄올로 추출하였을 때 약 $40 \mathrm{mg} \mathrm{GAE} / \mathrm{g}$ 으로 가장 높은 총 페놀 함랑을 나타내었 는데 본 연구의 총 폴리페놀과 차이가 나는 것은 실험에 사용한 표준물질의 차이 및 산사의 추출 조건, 건조 방법, 채취 시기, 재배 지역 등에 따른 차이에 의한 것으로 생각된 다.

\section{총 플라보노이드 함량}

플라보노이드는 C6-C3-C6를 기본 골격으로 하는 담황색 또는 노란색 계통의 페놀성 화합물의 총칭으로 직접 항산화 효소 활성을 증가시키거나 free radical을 소거시켜 항산화, 항염증, 항암 등 다양한 생리활성에 관여하는 것으로 알려 져 있다(37).

산사 추출물의 총 플라보노이드 함량을 정량한 결과를 Table 2에 나타내었다. 산사 추출물의 총 플라보노이드 함 량은 $18.94 \pm 0.4 \mathrm{mg} \mathrm{QE} / \mathrm{g}$ 으로 나타났다. Duan 등(38)이 보고 한 $70 \%$ 에탄올 추출물에서 $1.12 \pm 0.08 \mathrm{mg} \mathrm{QE} / \mathrm{g}$ 와 본 연구의 총 플라보노이드 함량이 차이가 나는 것은 산사의 추출 조건, 건조 방법, 채취 시기, 재배 지역 등에 따른 차이에 의한 것으로 생각된다.

\section{$\mathrm{Y}$-미로 시험에서 산사의 기억 개선 효과}

비선택적 무스카린성 아세틸콜린 수용체인 scopolamine 는 실험 동물을 이용하여 $\mathrm{AD}$ 연구에 가장 많이 사용하는 약물로 blood-brain barrier를 통과하여 초기 $\mathrm{AD}$ 증상과 유 사한 증상을 유발한다(39). Scopolamine을 투여한 기억력 감퇴 마우스를 이용하여 산사 추출물의 공간 학습 및 단기 기억 개선 효과를 확인하기 위하여 $\mathrm{Y}$ 미로 시험을 실시한 결과를 Fig. 1에 나타내었다. 정상인 NOR군의 자발적 변경
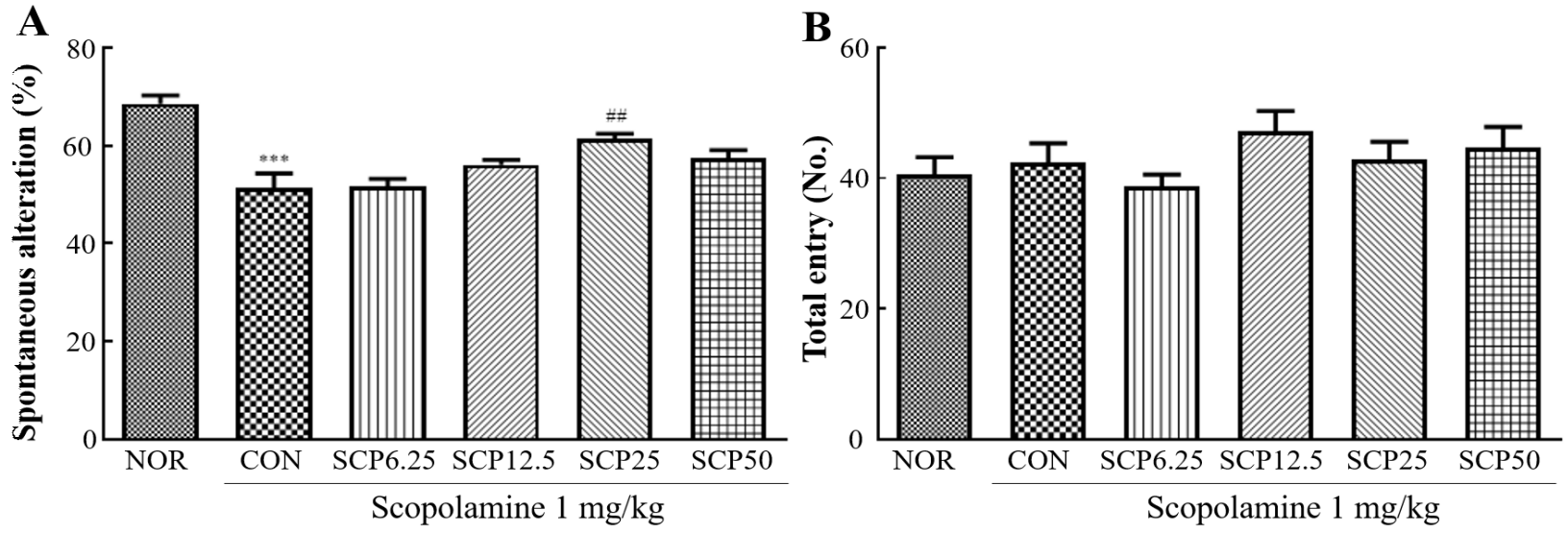

Fig. 1. Comparison of effects between Crataegus pinnatifida on the short-term, spatial reference memory of scopolamine-treated mice in Y-maze test.

A, spontaneous alteration; B, total entry.

Mice were administered SCP $(6.25,12.5,25$, or $50 \mathrm{mg} / \mathrm{kg})$ orally and intraperitoneally injected with scopolamine $(1 \mathrm{mg} / \mathrm{kg})$ after $30 \mathrm{~min}$. Data are expressed as mean $\pm \mathrm{SEM}$, $\mathrm{n}=9$ in each group. ${ }^{* *} \mathrm{p}<0.001$ compared with NOR group, \# $\mathrm{p}^{\circ}<0.01$ compared with the CON group. 
행동력은 $68.5 \pm 1.7 \%$, scopolamine의 투여로 인한 기억력이 손상된 $\mathrm{CON}$ 군은 $51.3 \pm 3.0 \%$ 로 NOR군과 비교하여 $74.9 \%$ 수준으로 감소하여 유의적인 차이를 나타내는 것을 확인 할 수 있었다 $(\mathrm{p}<0.001)$, 이는 단기 기억이 손상된 것으로 판단되어 scopolamine으로 인한 기억 손상 모델이 잘 작성 된 것을 의미한다. 추출물의 대량 생산을 가정하여 분무 건조한 산사 추출물 $6.25,12.5,25$ 및 $50 \mathrm{mg} / \mathrm{kg}$ 을 투여한 SCP6.25군, SCP12.5군, SCP25군, SCP50군에서 자발적 변 경행동력이 각각 $51.8 \pm 1.4 \%, 56.1 \pm 1.0 \%, 61.4 \pm 1.0 \%$, $57.3 \pm 1.7 \%$ 로 나타났고 이는 NOR군의 $75.5 \%, 81.8 \%$, $89.7 \%, 83.7 \%$ 수준으로 회복하는 것을 나타내었다. 이는

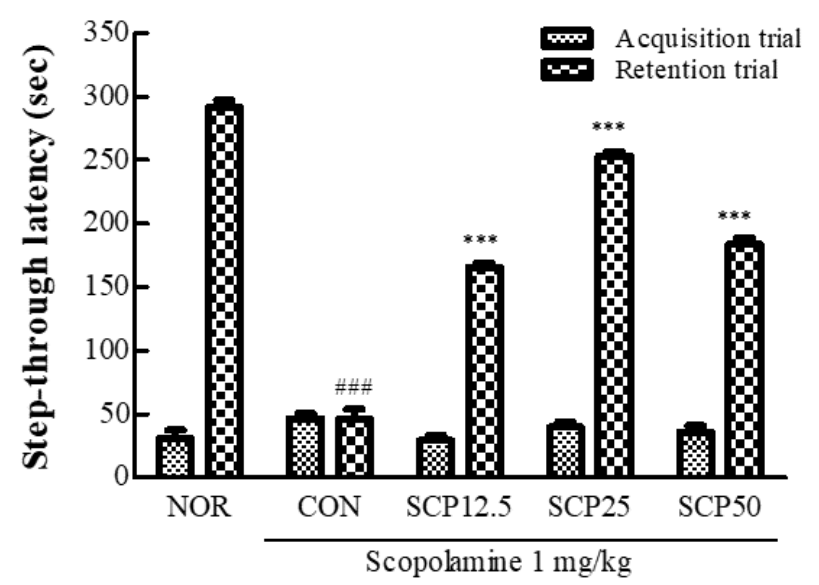

Fig. 2. Comparison of effects between Crataegus pinnatifida on the ability of learning and long-term memory of scopolamine-treated mice in passive avoidance test.

Mice were administered SCP $(12.5,25$, or $50 \mathrm{mg} / \mathrm{kg}$ ) orally and intraperitoneally injected with scopolamine $(1 \mathrm{mg} / \mathrm{kg})$ after $30 \mathrm{~min}$. Data are expressed as mean $\pm \mathrm{SEM}, \mathrm{n}=7 \mathrm{in}$ each group. ${ }^{* * *} \mathrm{p}<0.001$ compared with NOR group, \#\# $\mathrm{p}<0.001$ compared with the CON group.

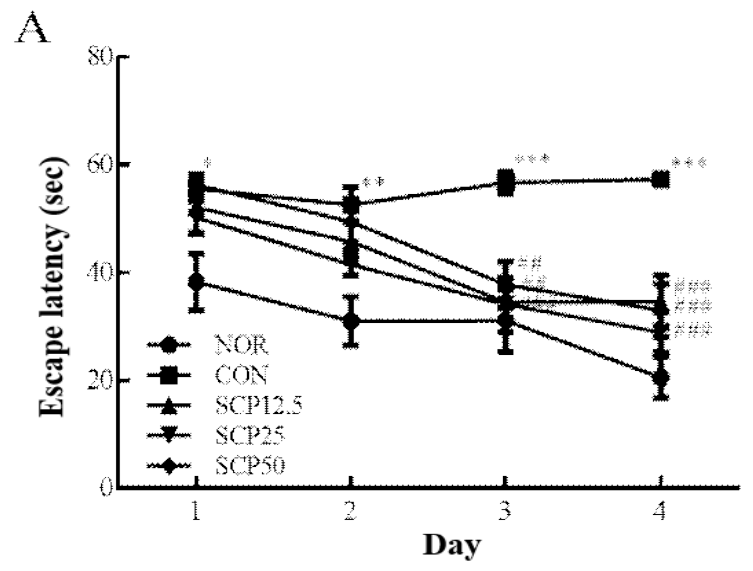

각 가지에 들어간 총 입장 횟수에서 각 실험군당 유의한 차이가 없었음으로 약물에 의한 행동 변화 없는 산사 추출 물에 의한 기억 개선 효과를 나타내었다. 또한 산사 추출물 의 용량 효과 관계는 고농도에서 기억력 개선 효과가 감소 하는 것을 확인 할 수 있었다. 그러나 산사 추출물이 인지 및 기억 개선 효과에서 전형적인 용량 의존적인 직선 관계 가 아닌 엎어진 U형의 용량 의존 관계를 나타냈는데 이는 $\mathrm{AChE}$ 억제제에서 독특하게 관찰되는 현상으로 적절한 농 도의 아세틸콜린은 기억을 강화시키지만 고농도에서는 콜 린성을 차단하여 기억을 손상시켜 일어나는 것으로 알려져 있다(40).

수동 회피 시험에서 산사의 기억 개선 효과

Scopolamine을 투여한 기억력 감퇴 마우스를 이용하여 산사 추출물의 공포 자극에 대한 학습 능력 및 장기 기억 개선 효과를 확인하기 위하여 수동 회피 시험을 실시한 결과를 Fig. 2에 나타내었다. 학습을 진행한 날에는 모든 실험군의 머무름 시간이 유의적인 차이가 없었으나 기억을 검사한 날에는 정상인 NOR군이 291.6 \pm 5.7 초, scopolamine 의 투여로 인한 기억력이 손상된 $\mathrm{CON}$ 군은 $46.0 \pm 7.8$ 초로 NOR군과 비교하여 $15.8 \%$ 수준으로 감소하여 유의적인 차 이를 나타내는 것을 확인 할 수 있었다 $(\mathrm{p}<0.001)$, 이는 scopolamine으로 인한 기억 손상 모델이 잘 작성된 것을 의미한다. 수동 회피 시험에서는 Y-미로 시험에서 가장 효 과가 미비하였던 산사 추출물 $6.25 \mathrm{mg} / \mathrm{kg}$ 를 제외하고 실험 을 진행하였다. 산사 추출물 $12.5,25$ 및 $50 \mathrm{mg} / \mathrm{kg}$ 을 투여한 $\mathrm{SCP} 12.5$ 군, $\mathrm{SCP} 25$ 군, $\mathrm{SCP} 50$ 군이 각각 $165.9 \pm 3.2$ 초, $253.4 \pm 3.2$ 초, $183.6 \pm 5.1$ 초로 나타나 NOR군의 $56.9 \%$, 산사 추출물 고농도에서 기억력 개선 효과가 감소하여 25

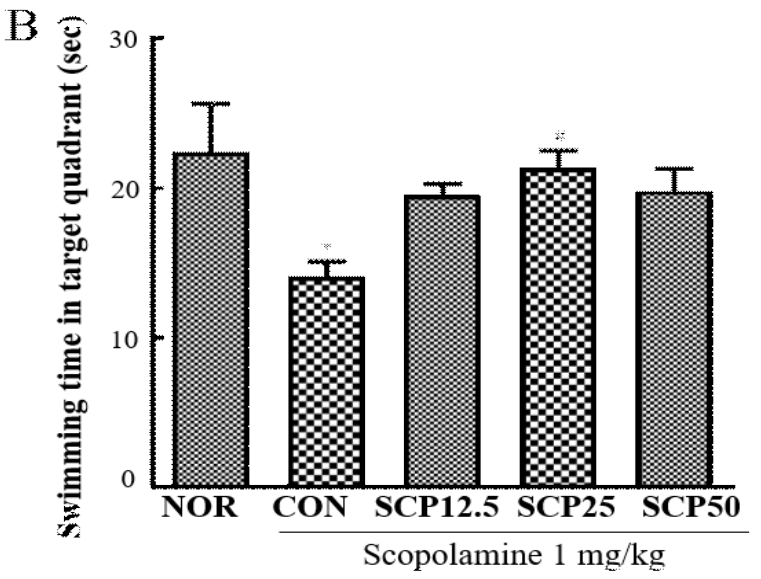

Fig. 3. Effects of Crataegus pinnatifida on the long-term, spatial reference memory of scopolamine-treated mice in Morris water maze test.

A, escape latency in acquisition phase; B, swimming time in target quadrant in probe trial

Mice were administered SCP $(12.5,25$, or $50 \mathrm{mg} / \mathrm{kg})$ orally and intraperitoneally injected with scopolamine $(1 \mathrm{mg} / \mathrm{kg})$ after $30 \mathrm{~min}$. Data are expressed as mean \pm SEM, $\mathrm{n}=10$ in each group. ${ }^{*} \mathrm{p}<0.05,{ }^{*} \mathrm{p}<0.01,{ }^{* * *} \mathrm{p}<0.001$ compared with NOR group, \#p $<0.01$, \#\# $\mathrm{p}<0.001$ compared with the CON group. 
$86.9 \%, 63.0 \%$ 수준으로 회복하는 것을 확인하였다. 이로서 $\mathrm{mg} / \mathrm{kg}$ 를 투여한 SCP25군에서 가장 좋은 기억 개선 효과를 나타내는 것을 확인 할 수 있었다.

\section{모리스 수중 미로 시험에서 산사의 기억 개선 효과}

Scopolamine을 투여한 기억력 감퇴 마우스를 이용하여 산사 추출물의 공간 학습 및 장기 기억 개선 효과를 확인하 기 위하여 모리스 수중 미로 시험을 실시한 결과를 Fig. 3에 나타내었다. 모든 실험군이 학습을 진행할수록 도피대 를 찾아가는데 걸리는 시간이 감소하였으나 scopolamine을 투여한 $\mathrm{CON}$ 군에서는 다른 군과 비교하여 감소되는 시간이 첫날과 비슷한 수준이었고, 정상인 NOR군과 비교하여 유 의하게 많은 시간이 걸렸다 $(\mathrm{p}<0.001)$. 이는 scopolamine 투 여로 인하여 도피대를 기억하지 못하는 것으로 판단되어 장기 기억 손상 모델이 잘 작성된 것을 의미한다. 산사 추출 물을 투여한 모든 실험군에서 학습 셋째 날부터 $\mathrm{CON}$ 군과 비교하여 유의하게 도피대를 찾아가는데 걸리는 시간이 감소하였으며 실험 마지막 날 진행한 probe test에서 NOR군

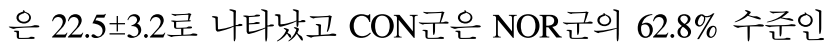
$14.1 \pm 1.0$ 초로 감소하여 공간 지각력 역시 손상 받은 것을 확인 할 수 있었고, $\mathrm{SCP} 12.5$ 군, $\mathrm{SCP} 25$ 군, $\mathrm{SCP} 50$ 군이 $\mathrm{NOR}$ 군의 $87.0 \%, 95.2 \%, 88.4 \%$ 수준인 $19.5 \pm 0.8$ 초, $21.4 \pm 1.1$ 초, $19.8 \pm 1.5$ 초로 손상된 기억이 개선되었고 특히 산사 추출물 $25 \mathrm{mg} / \mathrm{kg}$ 를 투여한 군에서 유의한 기억력 개선에 효과를 나타내는 것을 확인할 수 있었다 $(\mathrm{p}<0.05)$.

\section{산사의 $\mathrm{AChE}$ 저해 효과}

기억과 관련하여 cholinergic 신경계(41), glutamatergic 신 경계(42), GABAergic 신경계(43), serotonergic 신경계(44), adrenergic 신경계(45) 등이 알려져 있으나 특히 cholinergic 신경계와 밀접하게 연관되어 있다. $\mathrm{AD}$ 에서는 뉴런과 신경 접합부의 acetylcholine(ACh)의 수치가 중요한데 특징적으 로 cholinergic neuron의 소실이 나타나며 신경 전달 물질인

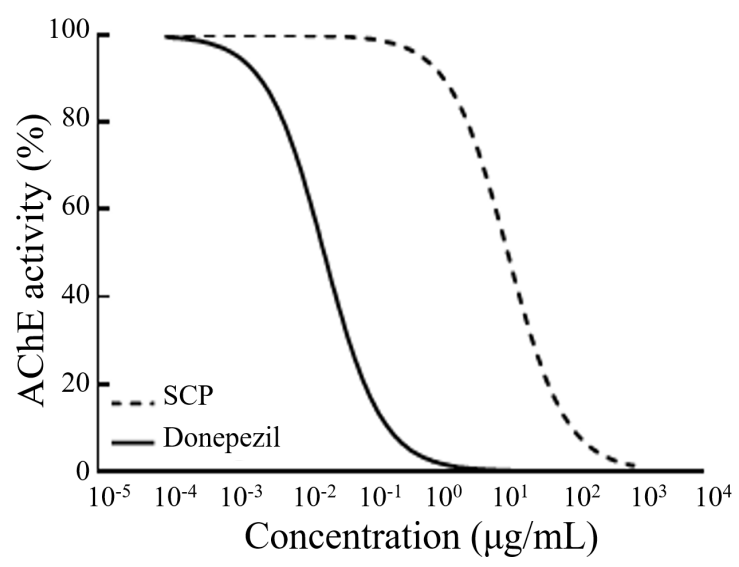

Fig. 4. Effects of Crataegus pinnatifida on the AChE activity.
$\mathrm{ACh}$ 이 부족해지며 인지 및 기억 손상이 야기된다. 따라서 임상에서는 $\mathrm{ACh}$ 의 분해하는 $\mathrm{AChE}$ 를 억제함으로 감소된 $\mathrm{ACh}$ 의 농도를 증가시킴으로써 $\mathrm{AD}$ 의 증상을 치료하고 $\mathrm{AD}$ 의 진행을 늦추고 있다(46).

균질화한 뇌의 상층액을 효소로 하여 분무 건조한 산사 인 $\mathrm{SCP}$ 의 $\mathrm{AChE}$ 의 저해능을 확인한 결과를 Fig. 4 에 나타내 었다. $\mathrm{SCP}$ 의 $\mathrm{IC}_{50}$ 값이 $12.76 \mu \mathrm{g} / \mathrm{mL}$ 로 나타났으며 양성 대조 군으로 사용한 $\mathrm{AChE}$ 억제제인 donepezil의 $\mathrm{IC}_{50}$ 값이 $0.02345 \mu \mathrm{g} / \mathrm{mL}$ 로 나타났다. 이는 분무 건조 시 들어간 덱스 트린에 의하여 $\mathrm{IC}_{50}$ 값이 높게 나타났을 것이라 판단되나 산사 추출물이 $\mathrm{AChE}$ 의 활동을 억제를 통하여 기억력을 개선시키는 것을 확인 할 수 있었다.

\section{요 약}

본 연구에서는 $60 \%$ 프레타놀을 이용하여 $60^{\circ} \mathrm{C}$ 에서 5 시 간 1 회 추출한 산사를 이용하여 영양성분 및 항산화능을 평가하고, 인지 및 기억력 개선 효과를 무스카린 수용체 저해제인 scopolamine 투여한 마우스 모델에서 행동 실험을 통하여 규명하며 마우스 뇌를 이용하여 $\mathrm{AChE}$ 저해능을 평가하였다. 산사에는 탄수화물 및 당류가 높고 지질류가 적으며 총 플라보노이드 함량이 풍부하여 약용식품으로 가치가 높은 것을 확인하였다. 이를 건강기능식품으로 대 량 생산하기 쉬운 분무 건조물을 이용하여 $\mathrm{Y}$ 미로 시험, 수동 회피 시험, 모리스 수중 미로 시험을 통하여 산사의 인지 및 기억 개선 효과를 확인하였다. 이에 대한 기전을 확인한 결과 산사 추출물이 $\mathrm{AChE}$ 를 억제하는 것을 확인 할 수 있었다. 본 연구 결과를 토대로 산사 $60 \%$ 프레타놀 추출물이 인지 및 기억력 개선 효과를 가지는 건강기능식품 으로의 개발 또는 섭취에 대한 중요성을 강조할 수 있는 근거 자료로 활용할 수 있을 것으로 판단된다.

\section{감사의 글}

이 논문은 과학기술정보통신부의 재원으로 연구개발특 구진흥재단-기술이전사업화 사업의 지원을 받아 수행된 연 구입니다(No. 2017DG00051/산사 추출물을 이용한 기억력 및 인지기능 개선용 개별인정형 건강기능식품 개발).

\section{References}

1. Lim HS, Kim BY, Kim YJ, Jeong SJ (2018) Phytochemical allylguaiacol exerts a neuroprotective effect on hippocampal cells and ameliorates scopolamine- 
induced memory impairment in mice. Behav Brain Res, 339, 261-268

2. Bondolfi L, Calhoun M, Ermini F, Kuhn HG, Wiederhold KH, Walker L, Staufenbiel M, Jucker M (2002) Amyloid-associated neuron loss and gliogenesis in the neocortex of amyloid precursor protein transgenic mice. J Neurosci, 22, 515-522

3. Villemagne VL, Dore V, Bourgeat P, Burnham SC, Laws S, Salvado O, Masters CL, Rowe CC (2017) Aß-amyloid and tau imaging in dementia. Semin Nucl Med, 47, 75-88

4. Nardone R, Holler Y, Bathke AC, Holler P, Lochner P, Tezzon F, Trinka E, Brigo F (2015) Subjective memory impairment and cholinergic transmission: a TMS study. J Neural Transm, 122, 873-876

5. Onyango IG, Khan SM (2006) Oxidative stress, mitochondrial dysfunction, and stress signaling in Alzheimer's disease. Curr Alzheimer Res, 3, 339-349

6. Tan ECK, Hilmer SN, Garcia-Ptacek S, Bell JS (2018) Current approaches to the pharmacological treatment of Alzheimer's disease. Aust J Gen Pract, 47, 586-592

7. Young JJ, Lavakumar M, Tampi D, Balachandran S, Tampi RR (2018) Frontotemporal dementia: latest evidence and clinical implications. Ther Adv Psychopharmacol, 8, 33-48

8. Ma HK, Liu Y, Li B, Zhang Y, Sun LJ, Xu FQ (2018) Chinese medicine for Alzheimer's disease: A meta-analysis of randomized controlled trials. Chin J Integr Med, 24, 938-943

9. Dong $\mathrm{P}$, Pan L, Zhang $\mathrm{X}$, Zhang W, Wang $\mathrm{X}$, Jiang M, Chen Y, Duan Y, Wu H, Xu Y, Zhang P, Zhu Y (2017) Hawthorn (Crataegus pinnatifida Bunge) leave flavonoids attenuate atherosclerosis development in apoE knock-out mice. J Ethnopharmacol, 198, 479-488

10. Wen L, Lin Y, Lv R, Yan H, Yu J, Zhao H, Wang $X$, Wang D (2017) An efficient method for the preparative isolation and purification of flavonoids from leaves of Crataegus pinnatifida by HSCCC and Pre-HPLC. Molecules, 22, E767

11. Wen L, Guo R, You L, Abbasi AM, Li T, Fu X, Liu RH (2017) Major triterpenoids in Chinese hawthorn "Crataegus pinnatifida" and their effects on cell proliferation and apoptosis induction in MDA-MB-231 cancer cells. Food Chem Toxicol, 100, 149-160

12. Gong $Y$, Yang Y, Chen X, Yang M, Huang D, Yang R, Zhou L, Li C, Xiong Q, Xiong Z (2017) Hyperoside protects against chronic mild stress-induced learning and memory deficits. Biomed Pharmacother, 91, 831-840
13. Liu CY, Bai K, Liu XH, Zhang LM, Yu GR (2018) Hyperoside protects the blood-brain barrier from neurotoxicity of amyloid beta 1-42. Neural Regen Res, 13, 1974-1980

14. Zheng M, Liu C, Pan F, Shi D, Zhang Y (2012) Antidepressant-like effect of hyperoside isolated from Apocynum venetum leaves: possible cellular mechanisms. Phytomedicine, 19, 145-149

15. Lim DW, Han T, Jung J, Song Y, Um MY, Yoon M, Kim YT, Cho S, Kim IH, Han D, Lee C, Lee J (2018) Chlorogenic acid from Hawthorn Berry (Crataegus pinnatifida Fruit) prevents stress hormone-induced depressive behavior, through monoamine oxidase B-reactive oxygen species signaling in hippocampal astrocytes of mice. Mol Nutr Food Res, 62, e1800029

16. Heitman E, Ingram DK (2017) Cognitive and neuroprotective effects of chlorogenic acid. Nutr Neurosci, 20, 32-39

17. Hu M, Li F, Wang W (2018) Vitexin protects dopaminergic neurons in MPTP-induced Parkinson's disease through PI3K/Akt signaling pathway. Drug Des Devel Ther, 12, 565-573

18. Wang Y, Zhen Y, Wu X, Jiang Q, Li X, Chen Z, Zhang G, Dong L (2015) Vitexin protects brain against ischemia/reperfusion injury via modulating mitogenactivated protein kinase and apoptosis signaling in mice. Phytomedicine, 22, 379-384

19. Guo R, Zhou L, Zhao P, Wang XB, Huang XX, Song SJ (2018) Two new sesquineolignans from the seeds of Crataegus pinnatifida and their $\beta$-amyloid aggregation inhibitory activitiy. Nat Prod Res, 1-7

20. Peng Y, Lou LL, Liu SF, Zhou L, Huang XX, Song SJ (2016) Antioxidant and anti-inflammatory neolignans from the seeds of hawthorn. Bioorg Med Chem Lett, 26, 5501-5506

21. Huang XX, Bai M, Zhou L, Lou LL, Liu QB, Zhang Y, Li LZ, Song SJ (2015) Food byproducts as a new and cheap source of bioactive compounds: Lignans with antioxidant and anti-inflammatory properties from Crataegus pinnatifida seeds. J Agric Food Chem, 63, 7252-7260

22. Tadic VM, Dobric S, Markovic GM, Dordevic SM, Arsic IA, Menkovic NR, Stevic T (2008) Anti-inflammatory, gastroprotective, free-radical-scavenging, and antimicrobial activities of hawthorn berries ethanol extract. J Agric Food Chem, 56, 7700-7709

23. Aierken A, Buchholz T, Chen C, Zhang X, Melzig MF 
(2017) Hypoglycemic effect of hawthorn in type II diabetes mellitus rat model. J Sci Food Agric, 97, $4557-4561$

24. Yoo JH, Liu Y, Kim HS (2016) Hawthorn fruit extract elevates expression of Nrf2/HO-1 and improves lipid profiles in ovariectomized rats. Nutrients, 8, E283

25. Luo M, Yang $X, \mathrm{Hu} J Y$, Jiao J, Mu FS, Song ZY, Gai QY, Qiao Q, Ruan X, Fu YJ (2016) Antioxidant properties of phenolic compounds in renewable parts of Crataegus pinnatifida inferred from seasonal variations. J Food Sci, 81, C1102-C1109

26. Shao F, Gu L, Chen H, Liu R, Huang H, Ren G (2016) Comparation of hypolipidemic and antioxidant effects of aqueous and ethanol extracts of Crataegus pinnatifida fruit in high-fat emulsion-induced hyperlipidemia rats. Pharmacogn Mag, 12, 64-69

27. Park SJ, Han KS, Yoo SM (2012) Nutritional characteristics and screening of biological activity of Crataegi frutus. Korean J Food Nutr, 25, 413-418

28. Lee JJ, Lee HJ (2012) Comparisons of physicochemical composition of Korean and Chinese Crataegi fructrus. Korean J Food Preserv, 19, 569-576

29. Folin O, Denis W (1912) On phosphotungsticphosphomolybdic compounds as color reagents. J Biol Chem, 12, 239-243

30. Moreno MIN, Isla MI, Sampietro AR, Vattuone MA (2000) Comparison of the free radical-scavenging activity of propolis from several regions of Argentina. J Ethnopharmacol, 71, 109-114

31. Han SH, Kim SJ, Yun YW, Nam SY, Lee HJ, Lee BJ (2018) Protective effects of cultured and fermented ginseng extracts against scopolamine-induced memory loss in a mouse model. Lab Anim Res, 34, 37-43

32. Ko YH, Kwon SH, Hwang JY, Kim KI, Seo JY, Nguyen TL, Lee SY, Kim HC, Jang CG (2018) The memory-enhancing effects of liquiritigenin by activation of NMDA receptors and the CREB signaling pathway in mice. Biomol Ther (Seoul), 26, 109-114

33. Reid SNS, Ryu JK, Kim Y, Jeon BH (2018) GABA-enriched fermented Laminaria japonica improves cognitive impairment and neuroplasticity in scopolamineand ethanol-induced dementia model mice. Nutr Res Pract, 12, 199-207

34. Ellman GL, Courtney KD, Andres V Jr, Feather-stone RM (1961) A new and rapid colorimetric determination of acetylcholinesterase activity. Biochem Pharmacol, 7, 91-95

35. Shahidi F, Janitha PK, Wanasundara PD (1992) Phenolic antioxidants. Crit Rev Food Sci Nutr, 32, 67-103
36. Nam SM, Kang IJ, Shin MH (2015) Anti-diabetic and anti-oxidative activities of extracts from Crataegus pinnatifida. J East Asian Soc Dietary Life, 25, 270-277

37. Husain SR, Cillard J, Cillard P (1987) Hydroxyl radical scavenging activity of flavonoids. Phytochemistry, 26, 2489-2491

38. Duan Y, Kim MA, Seong JH, Lee YG, Kim DS, Chung H, Kim H (2014) Impacts of various solvent extracts from wild Haw (Crataegus pinnatifida Bunge) pulpy on the antioxidative activities. J East Asian Soc Dietary Life, 24, 392-399

39. Bihaqi SW, Singh AP, Tiwari M (2012) Supplementation of Convolvulus pluricaulis attenuates scopolamine-induced increased tau and amyloid precursor protein (AßPP) expression in rat brain. Indian J Pharmacol, 44, 593-598

40. Newman LA, Gold PE (2016) Attenuation in rats of impairments of memory by scopolamine, a muscarinic receptor antagonist, by mecamylamine, a nicotinic receptor antagonist. Psychopharmacology, 233, 925-932

41. Guardia-Escote L, Basaure P, Blanco J, Cabre M, Perez-Fernandez C, Sanchez-Santed F, Domingo JL, Colomina MT (2018) Postnatal exposure to chlorpyrifos produces long-term effects on spatial memory and the cholinergic system in mice in a sex- and $A P O E$ genotype-dependent manner. Food Chem Toxicol, 122, 1-10

42. Soman S, Korah PK, Jayanarayanan S, Mathew J, Paulose CS (2012) Oxidative stress induced NMDA receptor alteration leads to spatial memory deficits in temporal lobe epilepsy: ameliorative effects of Withania somnifera and Withanolide A. Neurochem Res, 37, 1915-1927

43. Lamsa K, Lau P (2019) Long-term plasticity of hippocampal interneurons during in vivo memory processes. Curr Opin Neurobiol, 54, 20-27

44. Afshar S, Shahidi S, Rohani AH, Komaki A, Asl SS (2018) The effect of NAD-299 and TCB-2 on learning and memory, hippocampal BDNF levels and amyloid plaques in Streptozotocin-induced memory deficits in male rats. Psychopharmacology (Berl), 235, 2809-2822

45. Wang SH (2018) Novelty enhances memory persistence and remediates propranolol-induced deficit via reconsolidation. Neuropharmacology, 141, 42-54

46. Barai P, Raval N, Acharya S, Borisa A, Bhatt H, Acharya $N$ (2019) Neuroprotective effects of bergenin in Alzheimer's disease: Investigation through molecular docking, in vitro and in vivo studies. Behav Brain Res, 356, $18-40$ 